\title{
Does preoperative percutaneous nephrostomy insertion worsen upper-tract urothelial cancer oncological outcome? A retrospective single center study
}

\author{
Guan-Lin Huang ${ }^{\dagger}$, Hao-Lun Luo ${ }^{\dagger}$ and Po-Hui Chiang ${ }^{*}$
}

\begin{abstract}
Background: Physicians doubt percutaneous nephrostomy (PCN) insertion on cancer related hydronephrosis patients causes tumor seeding and worse cancer control. In this article, we attempted to determine if preoperative PCN alters cancer control in upper tract urothelial cancer (UTUC) patients.

Methods: Retrospective analysis of UTUC patients in a single center from 2005 to 2015. Exclusion criteria included lymph node metastasis, and patients underwent perioperative adjuvant chemotherapy or radiotherapy. There were 664 patients in this analysis, with clinico-pathological data being collected retrospectively for Cox-regression statistical analysis. Outcomes were measured by local recurrence, distant metastasis and cancer-specific death with Kaplan-Meier curves.
\end{abstract}

Results: There were respectively 25 and 639 UTUC cancers in the preoperative PCN and non-PCN insertion groups with mean follow-up duration of 37.9 and 48.6 months, respectively. The preoperative PCN group consisted of 17 patients (68\%) with tumor located in the ureter, while the PCN-negative group included 236 patients (36\%) with tumor located in the ureter being statistically significant. These two groups were comparable in gender, age, follow-up duration, tumor stage, and pathological features of the UTUC. As for the cancer control in the PCN group, $4(16 \%), 1(4 \%)$ and 1(4\%) had local recurrence, distant metastasis and cancer-specific death respectively; in the nonPCN group, 101(15.8\%), 96(15\%) and 72(11.2\%) exhibited local recurrence, distant metastasis and cancer-specific death respectively. Statistical analysis showed no difference in oncologic outcomes between these two groups. $(p=$ $0.804,0.201$ and 0.254 ).

Conclusions: Preoperative percutaneous nephrostomy on upper-tract urothelial cancer poses little risk on tumor seeding and could be considered as part of treatment strategy if renal function preservation is needed.

\section{Background}

Hydronephrosis with compromised renal function is one manifestation of upper tract urothelial cancer [1]. Before definitive upper tract urothelial cancer diagnosis, percutaneous nephrostomy (PCN) may be undertaken for severe infective hydronephrosis or impending renal failure for temporary disease control. Although tumor seeding and invasion through the percutaneous nephrostomy

\footnotetext{
* Correspondence: tuoa480713@yahoo.com.tw

Guan-Lin Huang and Hao-Lun Luo are Co-first authors.

Department of Urology, Kaohsiung Chang Gung Memorial Hospital and Chang Gung University College of Medicine, 123, Ta-Pei Road, Niaosung, Kaohsiung, Taiwan
}

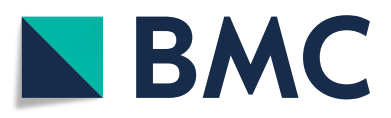

(c) The Author(s). 2019 Open Access This article is distributed under the terms of the Creative Commons Attribution 4.0 International License (http://creativecommons.org/licenses/by/4.0/), which permits unrestricted use, distribution, and

reproduction in any medium, provided you give appropriate credit to the original author(s) and the source, provide a link to the Creative Commons license, and indicate if changes were made. The Creative Commons Public Domain Dedication waiver (http://creativecommons.org/publicdomain/zero/1.0/) applies to the data made available in this article, unless otherwise stated.

tract has been reported on case reports [2,3], there are no studies comparing locally or systemically driven cancer recurrence rates between preoperative PCN dwelling and non-PCN dwelling patients in preoperative uppertract urothelial cancer patients. This study is the first study to analyze these two groups' of patients in the best of our knowledge.

\section{Methods}

We retrospectively collected upper-tract urothelial cancer patients receiving nephroureterectomy from 2005 to 2015 in single tertiary referring center. Procedures in the PCN group were initially intended for the preservation 
of deteriorating renal function or medical failure infective hydronephrosis with information of possible malignant tumor seeding through the PCN tract to patients. Interventional radiologist performed whole $\mathrm{PCN}$ group patients with Fr 10. nephrostomy tube or pigtail. Radical nephroureterectomy procedure cases were enrolled in the study for definite UTUC treatment. Peri-operative positive lymph nodes and distant organ metastasis cases were excluded due to poor prognosis and possible need of further adjuvant treatment; besides, neo-adjuvant or adjuvant candidates were also excluded for comparability of the disease course. Patient basic characteristics and pathological features were collected, such as age, gender, follow up duration, pathological stage, tumor figuration, tumor site, lymphovascular invasion, carcinoma in situ, multifocal, tumor necrosis, smoking and end stage renal disease. The follow-up protocol after nephroureterecotmy was as follows: 1.Computed tomography $(\mathrm{CT}) \mathrm{ab}-$ domen scanning every 3-6 months in the first 2 years and annually thereafter. 2. Cystoscopy every 3 months until 2 years shifted to every 6 months if negative finding. 3. Physical examination over the surgical wound and PCN tract during outpatient clinics visits, and CT scanning if suspicion of disease recurrence. Outcome measurements were classified as bladder recurrence, local recurrence, and distant metastasis. Follow-up cystoscopy showed merely bladder recurrence residual bladder cuffing recurrence was deemed as bladder recurrence. In PCN group, local recurrence was defined as disease recurrence over ipsilateral retroperitoneal space or PCN sites. In PCN negative group, local recurrence was defined as disease over the ipsilateral retroperitoneal space. Distant metastasis was defined as regional/distant lymph nodes metastasis or organ metastasis. We used Coxregression statistical analysis on comparability and significance of tumor recurrence between PCN (+) and PCN (-) groups. Kaplan-Meier survival curve was applied for time to recurrence between these two groups.

\section{Results}

In total, 25 patients in the $\mathrm{PCN}(+)$ group and 639 patients in the $\mathrm{PCN}(-)$ group had mean follow up duration of 37.9 and 48.6 months, respectively. The percentage of ureter tumor in the $\mathrm{PCN}(+)$ group $(68 \%)$ was higher than the $\mathrm{PCN}(-)$ group $(36 \%)$ with significant difference $(p=$ 0.002). The median PCN dwelling time was 18 days [IOR: 5-26] Other basic characteristics such as gender, age, tumor stage, tumor grade, lymphovascular invasion, were collected with no significant difference between these two groups (Table 1.)

As for the cancer control in the PCN group, 4(16\%), $1(4 \%)$ and $1(4 \%)$ had local recurrence, distant metastasis and cancer specific death respectively; in the non-PCN group, 101(15.8\%), 96(15\%) and 72(11.2\%) had local
Table 1 Patient demography and oncological outcome

\begin{tabular}{|c|c|c|c|}
\hline & $\begin{array}{l}\text { Preop PCN(+) } \\
n=25\end{array}$ & $\begin{array}{l}\text { Preop PCN(-) } \\
n=639\end{array}$ & \\
\hline Gender(Male/Female) & $11 / 14$ & $366 / 273$ & 0.189 \\
\hline Age(years) & $70.8 \pm 9.1$ & $67.17 \pm 10.8$ & 0.098 \\
\hline Follow up duration & $37.9 \pm 27.8$ & $48.6 \pm 31.4$ & 0.119 \\
\hline pT stage & & & 0.353 \\
\hline pTO & 6 & 181 & \\
\hline pT1 & 10 & 174 & \\
\hline pT2 & 5 & 122 & \\
\hline pT3 & 3 & 154 & \\
\hline pT4 & 1 & 8 & \\
\hline Papillary & 18 & 506 & 0.378 \\
\hline \multicolumn{4}{|l|}{ Tumor location } \\
\hline RP tumor & 4 & 264 & 0.011 \\
\hline U tumor & 17 & 236 & 0.002 \\
\hline $\mathrm{RP}+\mathrm{U}$ tumor & 4 & 138 & 0.790 \\
\hline High grade & 23 & 578 & 0.796 \\
\hline LVI & 6 & 97 & 0.232 \\
\hline $\mathrm{CIS}$ & 7 & 226 & 0.449 \\
\hline Multifocal & 9 & 189 & 0.491 \\
\hline TN & 7 & 184 & 0.931 \\
\hline Smoking & 5 & 65 & 0.116 \\
\hline ESRD & 5 & 132 & 0.937 \\
\hline Prior bladder $\mathrm{Ca}$ & 6 & 147 & 0.908 \\
\hline \multicolumn{4}{|l|}{ Oncological result } \\
\hline Bladder recurrence & 8 & 201 & 0.983 \\
\hline Local recurrence & 4 & 101 & 0.804 \\
\hline Distant metastasis & 1 & 96 & 0.201 \\
\hline Cancer specific death & 1 & 72 & 0.254 \\
\hline
\end{tabular}

$R P$ tumor renal pelvis tumor, $U$ tumor ureter tumor, $L V I$ lymphovascular invasion

CIS carcinoma in situ, TN tumor necrosis, ESRD end stage renal disease

recurrence, distant metastasis and cancer specific death respectively. Statistical analysis showed no cancer control difference between these two groups. $(p=0.804$, 0.201 and 0.254 )(Table 1.)

In the PCN group, no patients were found to have skin metastasis or PCN tract tumor invasion and the local recurrence pattern was over the ipsilateral retroperitoneal space, which is similar to PCN negative group. Besides, time to being local-recurrence free and time to being distant metastasis free in Kaplan-Meier survival curve showed no difference between these two groups. $(p=$ $0.804 \& 0.201)$ (Fig 1. \& Fig 2.)

\section{Discussion}

Tumor seeding after the percutaneous nephrostomy insertion has been reported in case reports but no study 


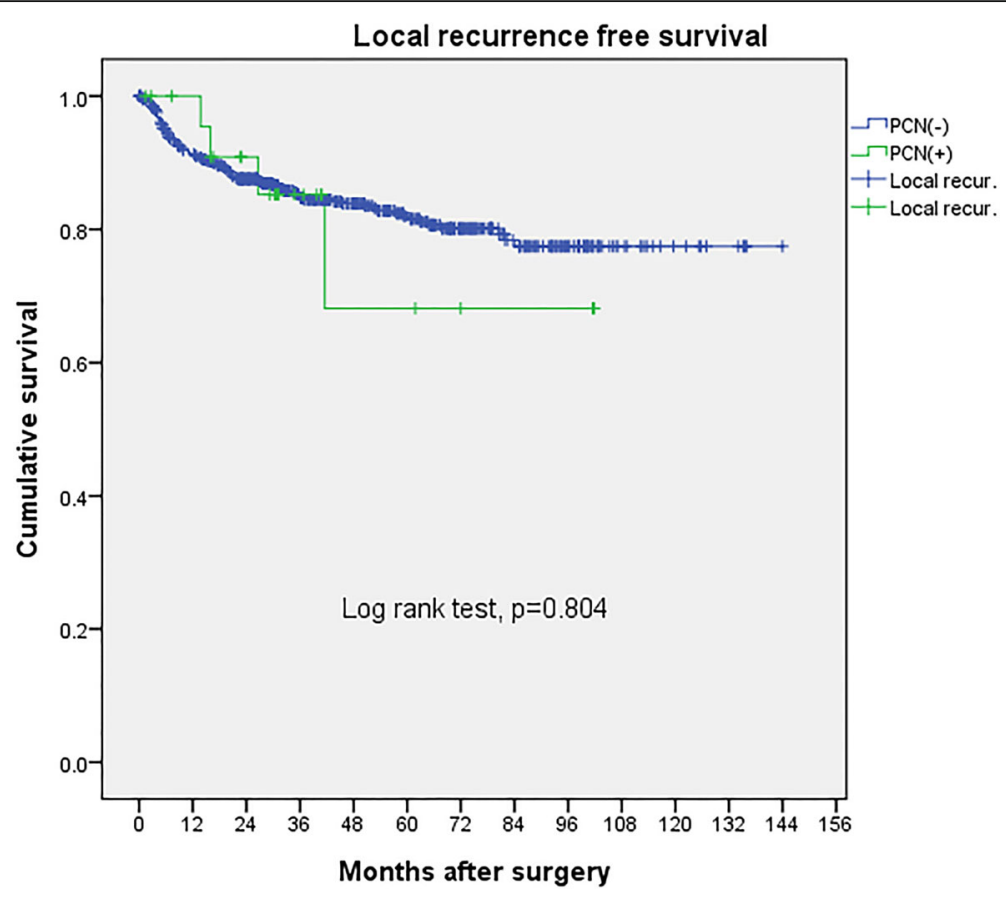

Fig. 1 Upper tract urothelial cancer local recurrence free survival after PCN

has evaluated if PCN procedure alter the risk of tumor seeding or cancer control [2-4]. In our study, the demographic and clinic-pathological data were similar between these two groups except for distribution of tumor location (17(68\%) and 236(52\%) ureter tumors in the PCN and nonPCN groups respectively, $p=0.002$ ). It is reasonable that ureteral tumors are often associated with more event of hydronephrosis and sometimes external drainage was sometimes inevitable. Besides, relieving the post-renal obstruction may be considered earlier than urothelial cancer management when presenting as severe renal function impairment. After standard radical nephroureterectomy, comparable local

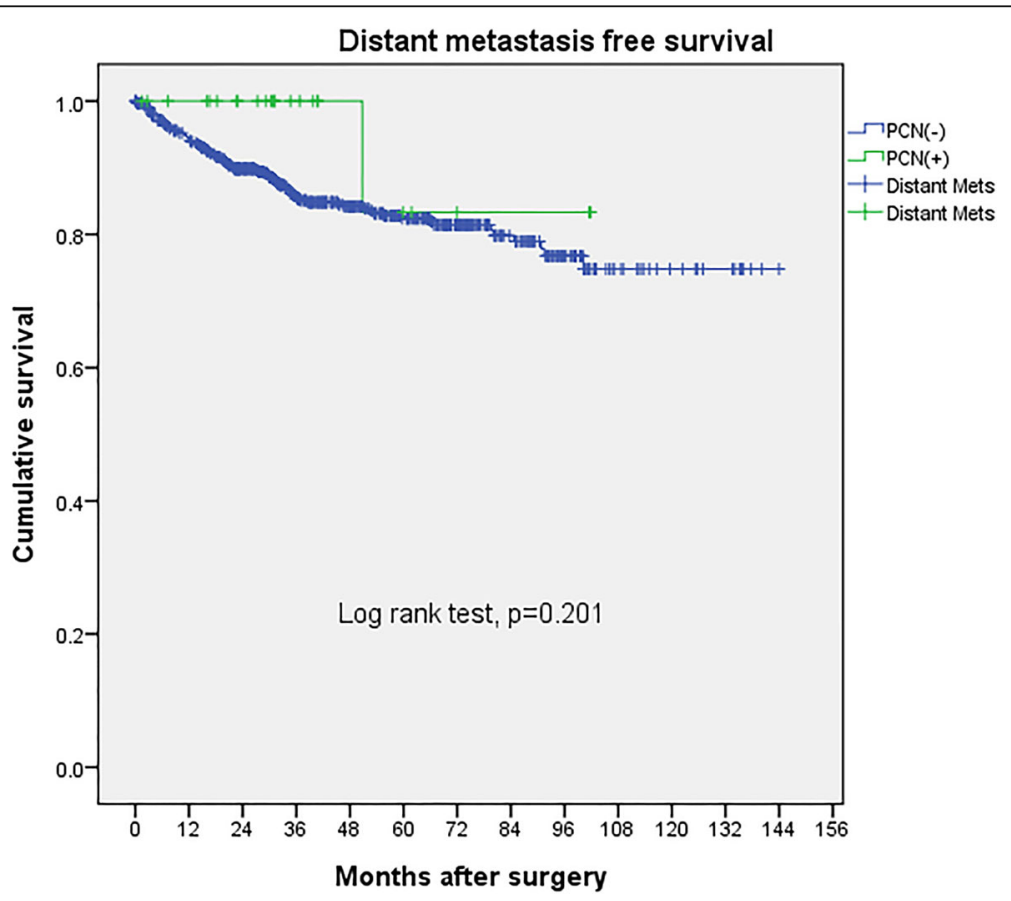

Fig. 2 Upper tract urothelial cancer distant metastasis free survival after PCN 
recurrence (PCN group vs non-PCN group: 4/25 vs 101/639, $16 \%$ vs $15.8 \%, p=0.804)$ and distant metastasis rate( $\mathrm{PCN}$ group vs non-PCN group: $1 / 25$ vs $96 / 639,4 \%$ vs $15 \%, p=$ 0.201 ) between these two groups were noted. Furthermore, there was no tumor dissemination along the PCN tract or skin metastasis observed in our study; hence, the risk of the worse oncological outcome related to the $\mathrm{PCN}$ procedure should not be over-emphasized especially for patients with need of salvaging residual renal function.

Table 2 Summarized the previous case reports of tumor seeding through the PCN tract [3-9]. Synchronous or metachronous urothelial cancer in upper urinary tract and bladder were the risk factors for tumor seeding [3-9]. Percutaneous endoscopic resection of the renal pelvis tumor seems another circumstance for tumor seeding [3-5, $8,9]$. However, Goel et al. reported long-term oncological outcomes of upper tract urothelial cancer status post percutaneous endoscopic resection, and concluded risk of tract seeding was low on low grade tumor [10]. Palou et al. also found percutaneous resection of superficial UTUC with good long term cancer outcome [11]. Roupret et al. retrospectively collected 24 patients receiving the percutaneous endoscopic resection of the tumor and reported 5-year disease-specific and tumor-free survival rates were 79.5 and $68 \%$. There was none track seeding in the study as well [12]. Serrano et al. reviewed articles in Medline regarding the cancer disseminating in the $\mathrm{PCN}$ tracts and concluded that risk of tumor seeding is very low, and there were still other explanation rather than $\mathrm{PCN}$ tract manipulation, like blood stream or lymphatic metastasis [13]. Through the PCN tract, percutaneous resection of upper tract urothelial cancer was an alternative option for preservation renal function with comparable long-term cancer control in low-grade and limited tumor size patients. Meanwhile, risk for the tumor seeding through the PCN tract should be informed but downplayed [10-12, 14, 15]. In addition, Kiss et al. mentioned that internal drainage within urinary tract may increase the risk or urothelial recurrence [16]. According to the reviewed literature, the external drainage carried low risk of recurrence and should be considered for relieving urinary obstruction.

In our study, 25 preoperative $\mathrm{PCN}$ patients were initially performed for relieving urinary obstruction and clinical diagnosis instead of percutaneous endoscopic manipulation; hence, the risk of tumor seeding and altered oncological outcomes was minimal after standard nephroureterectomy. In addition, the evidences of neoadjuvant chemotherapy are getting more and more and the oncologic result is inspiring $[17,18]$; however, impaired renal function is relatively contraindicated for cisplatin-based chemotherapy and such situation is not uncommon in clinical practice especially for UTUC patients $[19,20]$. The PCN drainage may preserve residual renal function for UTUC patients with hydronephrosis and can be considered as a treatment strategy before neoadjuvant chemotherapy.

\section{Limitation}

The article is retrospective with relatively small-sized populations with short PCN dwelling time(Median: 18 days, IQR: 5-26). The prognostic effect of tumor site can not be fully assessed due to such small cohort by

Table 2 Case reports of tumor seeding through PCN track

\begin{tabular}{|c|c|c|c|c|c|c|c|c|c|c|}
\hline Authors & $\begin{array}{l}\text { Sex } \\
M / F\end{array}$ & $\begin{array}{l}\text { Age, } \\
\text { years }\end{array}$ & $\begin{array}{l}\text { Concomitant } \\
\text { with bladder } \\
\text { cancer? }\end{array}$ & $\begin{array}{l}\text { Tumor } \\
\text { site }\end{array}$ & Histology & PCN function & $\begin{array}{l}\text { Definite } \\
\text { NUXBCE? }\end{array}$ & $\begin{array}{l}\text { PCN } \\
\text { dwelling } \\
\text { time }\end{array}$ & $\begin{array}{l}\text { Recurrence } \\
\text { site }\end{array}$ & $\begin{array}{l}\text { Time from } \\
\text { PCN to } \\
\text { recurrence }\end{array}$ \\
\hline $\begin{array}{l}\text { Sharma et al. } \\
1994 \text { [5] }\end{array}$ & $M$ & 56 & Yes & $R P, U$ & $\begin{array}{l}\text { UC, high } \\
\text { grade }\end{array}$ & PET & Yes & N.R. & $\begin{array}{l}\text { Nephrectomy } \\
\text { scar site }\end{array}$ & 8 months \\
\hline $\begin{array}{l}\text { Huang et al. } \\
1995 \text { [6] }\end{array}$ & $\mathrm{F}$ & 80 & Yes & U & $\begin{array}{l}\text { UC, high } \\
\text { grade }\end{array}$ & $\begin{array}{l}\text { Relief of } \\
\text { obstruction, AP } \\
\text { diagnosis }\end{array}$ & Yes & 30 days & $\begin{array}{l}\text { Nephrostomy } \\
\text { track }\end{array}$ & 1 month \\
\hline $\begin{array}{l}\text { Sengupta and } \\
\text { Harewood,1998 } \\
{[7]}\end{array}$ & $M$ & 78 & Yes & $\mathrm{RP}$ & $\begin{array}{l}\text { UC, high } \\
\text { grade }\end{array}$ & $\begin{array}{l}\text { Relief of } \\
\text { obstruction }\end{array}$ & Yes & N.R. & $\begin{array}{l}\text { Nephrostomy } \\
\text { track }\end{array}$ & 9 months \\
\hline $\begin{array}{l}\text { Yamada et al. } \\
2002 \text { [4] }\end{array}$ & $M$ & 63 & Yes & $\mathrm{RP}$ & $\begin{array}{l}\text { UC, low } \\
\text { grade(G2) }\end{array}$ & PET & Yes & 14 days & $\begin{array}{l}\text { Nephrostomy } \\
\text { track }\end{array}$ & 3 months \\
\hline $\begin{array}{l}\text { Treuthardt et al. } \\
2004 \text { [8] }\end{array}$ & M & 61 & Yes & $\mathrm{RP}$ & $\begin{array}{l}\text { UC, high } \\
\text { grade(G2) }\end{array}$ & PET & No & 6 weeks & $\begin{array}{l}\text { Nephrostomy } \\
\text { track }\end{array}$ & 12 months \\
\hline \multirow[t]{2}{*}{$\begin{array}{l}\text { Wang et al. } 2004 \\
\text { [9] }\end{array}$} & $\mathrm{F}$ & 63 & Yes & $R P, U$ & $\begin{array}{l}\text { UC, high } \\
\text { grade(G3) }\end{array}$ & $\begin{array}{l}\text { Relief of } \\
\text { obstruction }\end{array}$ & Yes & 7 days & $\begin{array}{l}\text { Nephrostomy } \\
\text { track }\end{array}$ & 3 months \\
\hline & $M$ & 52 & No & $\mathrm{RP}$ & $\begin{array}{l}\text { SCC, poor } \\
\text { differentiated }\end{array}$ & PET & Yes & 10 days & $\begin{array}{l}\text { Nephrostomy } \\
\text { track }\end{array}$ & 4 months \\
\hline $\begin{array}{l}\text { Sorokin et al. } \\
2013 \text { [3] }\end{array}$ & $M$ & 76 & Yes & $\mathrm{RP}$ & $\begin{array}{l}\text { UC, high } \\
\text { grade }\end{array}$ & PET & No & 2 months & $\begin{array}{l}\text { Nephrostomy } \\
\text { track }\end{array}$ & 5 months \\
\hline
\end{tabular}

UC urothelial cancer, N.R. not reported, SCC squamous cell carcinoma, $P C N$ percutaneous nephrostomy, NUXBCE nephroureterectomy with bladder cuff excision, $P E T$ percutaneous endoscopic treatment, $A P$ antegrade pyelography, $R P$ renal pelvis, $U$ ureter 
independent risk model. Further multi-center experience should be considered. Though the baseline asymmetry of ureteral tumor case between these two groups may cause of some bias, it reflect the real-world situation because that PCN was often used for preserving the residual function. The major size of PCN is eight to ten French in size and this study can further tell where if large size of PCN cause tumor seeding or not. However, this is the only study comparing PCN-related tumor seeding and oncological outcome, as we know.

\section{Conclusion}

Preoperative percutaneous nephrostomy on upper-tract urothelial cancer poses little risk on tumor seeding and could be considered as part of treatment strategy if renal function preservation is needed.

\section{Abbreviations \\ AP: antegrade pyelography; CIS: carcinoma in situ; CT: computed tomography; ESRD: end stage renal disease; LVI: lymphovascular invasion; NUXBCE: nephroureterectomy with bladder cuff excision; PCN: percutaneous nephrostomy; PET: percutaneous endoscopic treatment; RP tumor: renal pelvis tumor; RP: renal pelvis; SCC: squamous cell carcinoma; TN: tumor necrosis; TURBT: transurethral resection of bladder tumor; $\mathrm{U}$ tumor: ureter tumor; U: ureter; UC: urothelial cancer; UTUC: upper tract urothelial cancer}

\section{Acknowledgements}

Our team presented the preliminary abstract as poster on April 18 in 16th Urological Association of Asia Congress 2018 Kyoto, Japan. We are grateful to the poster participants giving directions for manuscript writing and precious clinical opinions.

\section{Authors' contributions}

GLH: data extract, manuscript and revision writing; HLL: statistical analysis, review data and revision writing direction; PHC: project development, revising and pictures production. All authors have read and approve of the final manuscript.

\section{Funding}

None to declare.

\section{Availability of data and materials}

The datasets used and/or analyzed during the current study available from the corresponding author on reasonable request.

\section{Ethics approval and consent to participate}

The current study was reviewed and approved by the institution review board (IRB) of the Kaohsiung Chang Gung Memorial Hospital (103-6335C). All participants provided written consent to participate in this study.

\section{Consent for publication}

Not applicable.

\section{Competing interests}

The authors declare that they have no competing interests.

Received: 6 April 2018 Accepted: 29 May 2019

Published online: 07 June 2019

\section{References}

1. Yeh HC, Jan HC, Wu WJ, et al. Concurrent preoperative presence of Hydronephrosis and flank pain independently predicts worse outcome of upper tract urothelial carcinoma. PLoS One. 2015;10:e0139624.

2. Schwartzmann I, Pastore AL, Sacca A, et al. Upper urinary tract urothelial carcinoma tumor seeding along percutaneous nephrostomy track: case report and review of the literature. Urol Int. 2017;98:115-9.
3. Sorokin I, Welliver RC Jr, Elkadi O, et al. Tumor seeding of percutaneous nephrostomy tract from urothelial carcinoma of the kidney. Case reports in urology. 2013;2013:819470.

4. Yamada Y, Kobayashi Y, Yao A, et al. Nephrostomy tract tumor seeding following percutaneous manipulation of a renal pelvic carcinoma. Hinyokika kiyo Acta urologica Japonica. 2002;48:415-8.

5. Sharma NK, Nicol A, Powell CS. Track infiltration following percutaneous resection of renal pelvic transitional cell carcinoma. Br J Urol. 1994;73:597-8.

6. Huang A, Low RK, deVere White R. Nephrostomy tract tumor seeding following percutaneous manipulation of a ureteral carcinoma. J Urol. 1995;153:1041-2.

7. Sengupta S, Harewood L. Transitional cell carcinoma growing along an indwelling nephrostomy tube track. Br J Urol. 1998;82:591.

8. Treuthardt C, Danuser H, Studer UE. Tumor seeding following percutaneous antegrade treatment of transitional cell carcinoma in the renal pelvis. Eur Urol. 2004:46:442-3.

9. Wang SS, Ho HC, Su CK, et al. Seeding of malignant renal tumor through a nephrostomy tract. Joumal of the Chinese Medical Association : JCMA. 2004;67:308-10.

10. Goel MC, Mahendra V, Roberts JG. Percutaneous management of renal pelvic urothelial tumors: long-term followup. J Urol. 2003;169:925-9 discussion 9-30.

11. Palou J, Piovesan LF, Huguet J, et al. Percutaneous nephroscopic management of upper urinary tract transitional cell carcinoma: recurrence and long-term followup. J Urol. 2004;172:66-9.

12. Rouprêt $\mathrm{M}$, Traxer $\mathrm{O}$, Tligui $\mathrm{M}$, et al. Upper urinary tract transitional cell carcinoma: recurrence rate after percutaneous endoscopic resection. Eur Urol. 51:709-14.

13. Serrano Pascual A, Fernandez Gonzalez I, Gonzalez-Peramato P, et al. Is there a risk of carcinoma dissemination in the percutaneous access for endoscopical treatment of upper urinary tract urothelial tumors? Arch Esp Urol. 2004;57:283-90.

14. Fiuk JV, Schwartz BF. Upper tract urothelial carcinoma: paradigm shift towards nephron sparing management. World journal of nephrology. 2016;5:158-65.

15. Stewart GD, Tolley DA. What are the oncological risks of minimal access surgery for the treatment of urinary tract Cancer? Eur Urol. 46:415-20.

16. Kiss B, Furrer MA, Wuethrich PY, et al. Stenting prior to cystectomy is an independent risk factor for upper urinary tract recurrence. J Urol. 2017;198:1263-8.

17. Porten $S$, Siefker-Radtke AO, Xiao L, et al. Neoadjuvant chemotherapy improves survival of patients with upper tract urothelial carcinoma. Cancer. 2014;120:1794-9.

18. Kubota Y, Hatakeyama S, Tanaka T, et al. Oncological outcomes of neoadjuvant chemotherapy in patients with locally advanced upper tract urothelial carcinoma: a multicenter study. Oncotarget. 2017;8:101500-8.

19. Kaag MG, O'Malley RL, O'Malley $P$, et al. Changes in renal function following nephroureterectomy may affect the use of perioperative chemotherapy. Eur Urol. 2010;58:581-7.

20. Lane BR, Smith AK, Larson BT, et al. Chronic kidney disease after nephroureterectomy for upper tract urothelial carcinoma and implications for the administration of perioperative chemotherapy. Cancer. 2010;116:2967-73.

\section{Publisher's Note}

Springer Nature remains neutral with regard to jurisdictional claims in published maps and institutional affiliations.
Ready to submit your research? Choose BMC and benefit from:
- fast, convenient online submission
- thorough peer review by experienced researchers in your field
- rapid publication on acceptance
- support for research data, including large and complex data types
- gold Open Access which fosters wider collaboration and increased citations
- maximum visibility for your research: over $100 \mathrm{M}$ website views per year
At $\mathrm{BMC}$, research is always in progress.
Learn more biomedcentral.com/submissions 